DOI: $10.19195 / 0137-1150.167 .19$

\author{
GIULIA BASELICA
}

Università degli Studi di Torino, Włochy

\title{
Павел Муратов и образ смерти в итальянском Возрождении
}

Павел Павлович Муратов, знаменитый историк искусства, писатель и переводчик, совершил своё первое путешествие в Италию в 1908 году. Он туда ездил в 1911 году и вернулся в Россию в августе следующего года; он снова там жил с мая до июля 1914 года. Уже после первого путешествия, Муратов начал работать над Образами Италии.

Среди возможных и многочисленных, иногда даже неожиданных, тематических путей, показывающих себя на разных уровнях чтения и толкования произведения Павла Муратова Образы Италии (1911-1912), обнаруживаются интересные философские и историко-культурные размышления о смерти, ставшие результатом вдохновления автора ${ }^{1}$ художественными наследием Кватроченто. Этот век русская культура включает в эпоху Возрождения, продолжающегося с начала XIV до конца XVII века².

${ }^{1}$ Первое издание этого произведения было опубликовано в двух томах в 1911-1912 годах, а второе, дополненное, вышло уже в 1912-1913 годах. Великий интеллигент эмигрировал в Италию в ноябре 1923 года. Он поселился в Риме и там жил до 1928 года, потом он переехал в Париж. Р. Deotto, Pavel Muratov, [в:] Russi in Italia, http://www.russinitalia.it/ dettaglio.php?id=12 [дата обращения: 12.08.2017].

2 См.: О. Ф. Кудрявцев, Возрождение, [в:] Культура Возрождения. Энциклопедия, т. I, Москва 2007, с. 356-359. В итальянских и западно-европеиских исследованиях Кватроченто относится, скорее, к эпохе Гуманизма, которая продолжалась приблизительно с начала XIV века до последней четверти XV века. Название Возрождение, Rinascita впервые употребил знаменитый художник, архитектор и писатель Джорджо Вазари, а понятие Renaissance распространилось в Европе благодаря знаменитому произведению Культура Возождения в Италии (Die Kultur der Renaissance in Italien), написанному Якобом Бурхардтом и опубликованному в 1860 году в Швейцарии, хотя термин уже использовался в 1855 году в девятом томе (La Renaissance) объемной Истории Франции Мишле. Тем не менее, смотря на культуру XV века, трудно противопоставлять торжествуюший Гуманизм зачаточному Возрождению, а в переходе из XV в XVI столетие культурное наследие производит впечатление о процессе созревания, а не противоположности. См.: E. Garin, La 
Павел Муратов прославлял Кватроченто: оно ему казалось настоящим произведением искусства, возникающим из мертвых веков. Он считал, что любой человек понимает эту эпоху взглядом, дыханием, осязанием; словом: к нему он применял тот же подход, которого требует современность. Русский искусствовед разделял идеи и убеждения Патера, который так ярко и восторженно выразил свое представление об этом столетии. Интерес к Возрождению, по мнению Патера, заключается в основном в феномене итальянской культуры, а точнее, в Кватроченто, в том торжественном Кватроченто, которое никогда не будет достаточно изученным, а не только в его положительных итогах в области научных трудов, в его конкретных произведениях искусства, в его типических выдающихся личностях со своим глубоким эстетическим обаянием. Интерес к эпохе Возрождения объясним самим его духом, этическими качествами, совершенные образцы которых оно дарит каждым своим выражением ${ }^{3}$.

В эпоху Кватроченто, как ни в какую другую эпоху, не интересовались идеей смерти с таким постоянством и с таким упорством, - подчеркивает Йохан Хейзинга ${ }^{4}$, а Муратову смерть самого XV столетия является под видом онирического состояния или сна:

Ее смерть больше похожа на сонный плен - тот плен, который держит в своих легких оковах людей Флоренции, изваянных флорентийскими скульпторами на флорентийских гробницах. Чуть заметная гордая улыбка на их тонких губах знаменует счастливейшую победу человечества, победу над смертью5.

cultura del Rinascimento. Dietro il mito dell'età nuova, Milano 2000). О хронологической позиции Ренессанса (или Возрождения) интересно пишет Михаил Соколов, предлагая сверхисторическое и одновременно неопределённое толкование этого понятия: „Ренессанс выглядит в кругу великих, метаисторических эпох чем-то наиболее зыбким и прихотливым, выглядит такой хронотопической данностью, которая в равной мере может быть вполне реальной, прочно установившейся в памяти времен, и нереальной, несбывшейся, утраченной в качестве эпохального приоритета”. М. Н. Соколов, По следам ,несбывшегося Ренессанса", [в:] Италия и русская культура, отв. ред. Н. П. Комолов, Москва 2000, с. 48.

${ }^{3}$ См.: W. Pater, The Renaissance. Studies in Art and Poetry, Mineola-New York 2013, c. 4. Во время пребывания в 1906 году в Лондоне именно из произведений Патера (и от трудов Вернона Ли и Бернарда Беренсона) Павел Муратов получил знании об итальянском искусстве. Таким образом он приготовился к экстатическому опыту первого путешествия в Италию, которое он совершит через два года. Своим выбором исследовательского направления в изучении итальянского Возрождения, указанного эклектическим Патером, Муратов утверждает преобладание эстетики над историей, и в основе субъективного понятия о красоте он определяет единственный критерий оценки. Применяя философию красоты ко всем искусствам - к литературе, музыке, скульптуре и живописи, он изображает представление о гезамткунстверке. См.: D. Beaune-Gray, L'itinéraire intellectuel de Pavel Muratov (18811945), http://russie-europe.ens-lyon.fr/article.php3?id_article=46 [дата обращения: 16.08.2017].

${ }^{4}$ См.: J. Huizinga, Autunno del Medioevo, пер. B. Jasinsk, Milano-Rizzoli 2004.

5 П. П. Муратов, Образы Италии. Исторический путеводитель, Москва 2016, с. 124. Далее цитаты приводятся по этому изданию с указанием страницы в скобках. 
Образ великого Микеланджело, проникнутого трагическим смыслом человеческой жизни и истории ${ }^{6}$, идеально сопровождает исход века, и Патер в его поэзии видит благороднейщее представление о смерти: она является настоящей любовницей художника и из ужасной беды превращается в духовное высшее состояние, далекое от всяких грубых, земных потребностей 7 . Представление Патера созвучно с философским наставлением Марсилио Фичино, который является одной из самих характерных личностей эпохи 8 . Рожденный под Сатурном, с меланхолическим темпераментом, он представляет собой новый тип философа, с недавних пор уже знакомого Европе: он моралист и врач, маг и астролог ${ }^{9}$. В своем трактате Платоновское богословие о бессмертии души, опубликованном в 1482 году, он заявляет, что телесные существа получают одно нетелесное существо - душу, которая порождает жизнь и смысл жизни даже из неживущей грязи, а над душой стоят ангелы ${ }^{10}$. На духовном и интеллектуальном уровне нетелесные и неземные существа определяют условия разрушения уничтожающей силы смерти, образуя таким образом непрерывную связь между чувственно воспринимаемым и сверхчувственным миром. И в поэзии, и в некоторых скульптурах Микеланджело, в частности расположенной на гробницах флорентинской капеллы Медичи, Муратов видит высокое прославление ночи и сна; ночь - это тень смерти, а сон, напоминая призывание Фичино, может освобождать душу, указывая ей дорогу в небесные просторы. Сам Микеланджело, полагает великий русский искусствовед, „не должен был знать печали, даже когда глядел прямо в лицо смерти. Ей одной вверено освобождение духа из плена жизни” [c. 156], что както напоминает взгляд Патера на мировоззрение флорентинского художника.

Образы ангелов, описанных в трактате Платоновское богословие о бессмертии души Фичино, встречаются в произведениях малоизвестного, но достойного художника Мелоццо да Форли. На его фреске Христос во славе в Квиринальском дворце в Риме показано бесконечное множество ангелов, причем далеко не однообразных: каждая фигура отличается выражением лица или положением тела, или манерой молиться Богу. Каждая

${ }^{6}$ E. Garin, La cultura del Rinascimento. Dietro il mito dell'età nuova, Milano 2000.

${ }^{7}$ Cм.: W. Pater, The Renaissance. Studies in Art and Poetry, Mineola-New York 2013, c. 60-61.

8 „В созданном им новом интеллектуальном климате коренные идеи эпохи формулировались вполне определенно, позволяя ренессансной культуре познать в их конечный смысл своих разнообразных проявлений”. О. Ф. Кудрявцев, Фичино, [в:] Культура Возрождения. Энциклопедия, т. II (2), Москва 2011, с. 435.

${ }^{9}$ E. Garin, L'uomodelRinascimento, Roma-Bari 2005.

10 В самом начале трактата он так побуждает читателей к превышению земных пределов: „Давайте, небесные духи, жаждущие небесной родины, быстро освободимся от цепей земных дел, чтобы летить, платоническими крылями и под наставлением Бога, в небесное пространтсво, откуда мы, блаженные, будем любоваться совершенством нашего рода". M. Ficino, Theologia platonica o De Immortalitate animarum, https://books.google.it/books?i$\mathrm{d}=\mathrm{QTt}$ 9wV3nnIwC\&printsec $=$ frontcover\&hl $=\mathrm{it} \&$ source $=$ gbs_ge_summary_r\&cad $=0 \# \mathrm{v}=$ onepage\&q\&f=false [дата обращения: 18.08.2017]. Перевод наш. — G. В. 
из них рассказывает историю, связанную с особой человеческой душой, поскольку, как учил Фичино, над душами стоят ангелы, а в эпохе восхваления человеческой индивидуальности можно верить в соответствие между количеством ангелов и количеством человеческих душ. Этому ангельскому множеству поручено высокое задание: помогать человеческим существам освободиться от земных цепей, чтобы лететь в небесное пространство. Муратов находит в совсем немногочисленных произведениях Мелоццо какоето глубокое и точное ощущение кончины эпохи, духа смерти: „Мелоццо не избежал душевных недугов умирающего кватроченто, породнивших прелесть его искусства с прелестью Боттичелли, Леонардо, Эрколе Роберти, Брамантино и даже Беллини и Джорджоне" [с. 289].

Учителем Мелоццо был Пьеро делла Франчеса, искусство которого „всеитальянское” [с. 449]. Этому знаменитому художнику и теоретику искусства в своих Образах Муратов уделяет много внимания, и среди разных шедевров он упоминает Воскресение Христа, простую и одновременно роскошную фреску, которую художник закончил к 1463 году во Дворце Консерваторов Палаццо-деи-Консерватори, который находится в его родном городе Сан Сеполкро. В этом произведении мы находим интересное выражение темы смерти и ее преодоления через антономастическое ее изображение: окончательная победа над смертью - через воскрешение Христа. Муратов здесь задерживается на описании Христа, теперь смотрящего за человечеством; на образе уснувших глубоким сном воинов и на очаровании весенней зари, символически связанной с пустой гробницей. Муратов, изображая в центре ирреалистического пейзажа появление Христоса с роковым и равнодушным, но со стоическим выражением лица ${ }^{11}$, утвержает таким образом хроматическое богатство целой фигуры и человеческий компонент божественного явления. Пьеро делла Франческа, как Мазаччо и другие представители живописного Возрождения, в своих фресках определил и установил физическую модель человека, которого культура этой эпохи считала привилегированным существом, владеющим светом ${ }^{12}$, и именно в таком представлении идеального положения человека скрывается мечта о вечности и о победе над смертью.

Искусство Пьеро делла Франческа ведет Муратова в Феррару, где художник жил и работал, передавая свое мастерство другому важному представителю итальянского Возрождения - Андреа Мантенья.

Муратов включает Феррару в число ,умерших городов Италии, как Пиза, Равенна, Венеция" [с. 83-84]. Она ему напоминает кладбище, а от остальных упомянутых городов она отличается тем, что „ни один из этих городов не представляет в такой полноте, как Феррара, благородного зрели-

${ }^{11}$ См.: R. Longhi, Piero della Francesca, [в:] его же, Da Cimabue a Morandi, Milano 1982, c. $349-465$.

12 E. Garin, La cultura del Rinascimento. Dietro il mito dell'età nuova, Milano 2000. 
ща естественного умирания вещей, в которых некогда воплощались человеческие верования, страсти и способности" [с. 83-84]. Теперь она молчит, в ней больше не складывают свои песни такие поэты, как Боярдо, Ариосто (его знаменитая рыцарская сказка Нейстовый Орландо (1516) в первой четверти XV столетия представляла новое, изысканное мировоззрение, затененное сознанием грозящего кризиса с неизбежно роковым концом эпохи) или Тассо, „и молчание нигде не является таким торжественным знамением смерти, как в этом городе” [с. 83-84].

Смерть является отличительной чертой города Венеции: уже в культуре эпохи Возрождения образ Венеции вызвал художественно-литературный миф противопоставления жизни и смерти, а тема смерти Венеции в самом начале XX века занимает значительное место в русских прозаических и поэтических произведениях. Публицисту и литературному критику Дмитрию Философову, оказавшемуся в Венеции в 1902 году, она казалась мертвой. Эта тема вдохновляла поэтов „серебряного века” - современников Муратова ${ }^{13}$, таких как Валерий Брюсов, Александр Блок, Николай Гумилев, Осип Мандельштам. Главными чертами умирающей Венеции традиционно являются тема воды и черный цвет. Последний обычно связан с образом смерти: он относится к гондолам и, следовательно, если применить метонимическое расширение, то и к самой Венеции. А тема воды актуализирует происхождение города - с мифологической реминисценцией к богине Венере, поднимающейся из моря, - и одновременно его будущего конца: в воде он родился и в воду вернется. Муратов своеобразно относится к теме венецианской воды: вода здесь не связана с идеей смерти, а - с идеей нового рождения. Венецианская лагуна превращается в Летейские воды, чистящие и утешающие усталые души путешественника с севера: „Для нас, северных людей, вступающих в Италию через золотые ворота Венеции, воды лагуны становятся в самом деле летейскими водами. [...] Все, что осталось позади, вся прежняя жизнь становится легкой ношей” [с. 11].

Автор Образов Италии останавливается далее на искусстве Джованни Беллини, представителя венецианского Кватроченто - величайшего и неутомимого гения-творителя ${ }^{14}$, - которого он считает венецианцем из венецианцев. Его многочисленные изображения Богоматери выражают чувство крайней простоты и особую задумчивость, которая обнаруживает отчужденность от всяких мыслей и всяких чувств и подсказывает мгновение перехода из бдения в сон, из жизни в смерть. Муратов отмечает, что именно на это невыразимое мгновение Беллини обращает внимание в произведении Свящуенная аллегория (1490-1499): в Галерее Уффици

${ }^{13}$ Н. Е. Меднис, Венеция в русской литературе, Новосибирск 1999.

${ }^{14}$ R. Longhi, Viatico per cinque secoli di pittura veneziana, [в:] его же, Da Cimabue a Morandi, Milano 1997, c. 622-686. 
оно выделяется особенной чистотой, глубочайшим покоем и религиозным торжеством. Каждая деталь картины, каждая форма и каждый цвет представляют собой особое изображение „Светлейшей”, и „мысль о Венеции неизменно овладает душой" ${ }^{\prime 15}$.

В рассказе Морто да Фельтре 16 (1918) Муратов сближает с манерой Беллини последних лет некоторые произведения Лоренцо Луццо, по прозванию Морто да Фельтре, который долго работал в Венеции и в других городах Венецианской республики в самом конце XV и в начале XVI веков. Искусствовед напоминает читателям интересную картину, написанную художником на кассоне в Сан Джорджо Маджоре. Здесь тема смерти подчеркнута повторением и соответствием изображений. Она проявляет себя в самих персонажах, в обычной жизни и в воспоминаниях средневековой иконографической традиции:

На длинной доске мы видим ряд сцен, теперь вполне понятных нам: молодую девушку в золотом платье, покоящуюся в открытом саркофаге под мраморным навесом причудливой формы на тонких колонках, приближающихся к ней людей с длинными бородами, в чалмах и восточных одеждах, как заблагорассудилось Лоренцо изобразить своих разбойников, а по другую сторону - юношей с тесно обтянутыми ногами, несущих на плечах закрытый гроб, и еще дальше группу ландскнехтов с копьями, среди которых шествует некто в образе скелета. Все это на фоне пейзажа серых скал с безлиственными деревьями, за которыми виднеются голубые горы, усеянные далекими замками ${ }^{17}$.

В сцене, описанной Муратовым, мы узнаем с одной стороны, отличительные элементы Триумфа смерти, так как образ скелета совмещается с представлением о том, как к чему приводит смерть, с другой - мы видим двойственное отношение к образу смерти в ту эпоху ${ }^{18}$ : молодая и красивая женщина покоится в открытом саркофаге, а юноша, обезображенный в битве, лежит в закрытом гробе. Тем не менее на более глубоком уровне смысла Танатос здесь не торжествует безраздельно: в господстве над светом с ним соперничает Эрос ${ }^{19}$. Главные герои живописной композиции - девушка и молодой человек, которые любят друг друга, а их похороны воспринимаются как вечная свадьба. Тема триумфа смерти характеризует это произве-

15 Там же.

16 Рассказ включен в сборник Герои и Героини, впервые опубликован в Москве в 1918 году.

17 П. П. Муратов, Морто да Фельтре, [в:] его же, Эгерия. Роман и новелль,, Москва 1997, c. 343.

18 M. Vovelle, La mort et l'Occident de 1300 à nos jours, Paris 1983.

19 Стоит здесь привести следующее замечание Руфа Хлодовского: „В средневековом и прежде всего в итальянском художественном сознании любовь и смерть - слова родственные, внутренне близкие и потому созвучные. Созвучие их, как известно, освящено создателем Божественной Комедии". Р. И. Хлодовский, Amore, Roma e Morte. Tютчев, Пушкин, Данте, [в:] Россия и Италия. Встреча культур, отв. ред. Н. П. Комолов, Москва 2000, c. 97. 
дение свадебной живописи раннего Возрождения. На самом деле, картину Морто да Фельтре написал ,для какой-нибудь дружеской свадьбы”20.

Путь в искусстве и культуре Кватроченто влечет за собой неоднократную встречу с многообразным понятием о смерти, и Муратов воспринимает каждый его оттенок. Перед ним художественно-философская переработка темы смерти обнаруживает себя в перспективе и религиозного и светского мировоззрения. Светская культура изображает смерть как средство освобождения от жизненной тяжести и как увековечивание человеческих поступков, а религиозная культура идентифицирует смерть с преходящим измерением к воскресению. Таким образом, оба направления, соответствующие двум противоположным интонациям эпохи Возрождения, хотя и следуя разными путями, приписывают смерти порождающую силу, от которой происходит новое рождение, или собственно Возрождение.

\section{Библиография}

Бердяев Н. А., Философия творчества, культуры и искусства, т. I, Москва 1994.

Кудрявцев О. Ф., Возрождение, [в:] Культура Возрождения. Энциклопедия, т. I, Москва 2007. Кудрявцев О. Ф., Фичино, [в:] Культура Возрождения. Энииклопедия, т. II (2), Москва 2011. Меднис Н. Е., Венеция в русской литературе, Новосибирск 1999.

Муратов П. П., Образы Италии. Исторический путеводитель, Москва 2016.

Муратов П. П., Эгерия. Роман и новелль, Москва 1997.

Соколов М. Н., По следам ,несбывшегося Ренессанса", [в:] Италия и русская культура, отв. ред. Н. П. Комолов, Москва 2000.

Хлодовский Р. И., Amore, Romae Morte. Тютчев, Пушкин, Данте, [в:] Россия и Италия. Встреча культур, отв. ред. Н. П. Комолов, Москва 2000.

Beaune-Gray D., L'itinéraire intellectuel de Pavel Muratov (1881-1945), http://russie-europe.enslyon.fr/article.php3?id_article $=46$.

Deotto P., Pavel Muratov, [в:] Russi in Italia, http://www.russinitalia.it/dettaglio.php?id=12.

Ficino M., Theologia platonica o De Immortalitate animarum, https://books.google.it/books?id=QTt9wV3nnIwC\&printsec $=$ frontcover\&hl $=\mathrm{it} \&$ source $=$ gbs_ge_summary_ $\mathrm{r} \& \mathrm{cad}=0 \# \mathrm{v}=\mathrm{o}-$ nepage \&q\&f=false.

Garin E., L'uomo del Rinascimento, Roma-Bari 2005.

Garin E., La cultura del Rinascimento. Dietro il mito dell'età nuova, Milano 2000.

Huizinga J., Autunno del Medioevo, nep. B. Jasinsk, Milano-Rizzoli 2004.

Longhi R., Piero della Francesca, [в:] его же, Da Cimabue a Morandi, Milano 1997.

Longhi R., Viatico per cinque secoli di pittura veneziana, [в:] его же: Da Cimabue a Morandi, Milano 1997.

Pater W., The Renaissance. Studies in Art and Poetry, New York 2013.

Vovelle M., La mort et l'Occident de 1300 à nos jours, Paris 1983.

${ }^{20}$ П. П. Муратов, Морто да Фельтре, [в:] его же, Эгерия. Роман и новелль, Москва 1997, c. 342. 


\section{Pavel Muratov and the image of death in the Italian renaissance}

\section{Summary}

The article is an analytical path throughout some cultural phenomena - of a philosophical, literary and artistic nature - stemming from a classical and Renaissance reworking of the theme of death, as interpreted by Pavel Muratov, the author of the famous work Образы Италии (Immagini d'Italia), published in Moscow in the first decade of the twentieth century. The outstanding art historian many a time ponders over the concept and image of death, which inspired artists like Giovanni Bellini, Piero della Francesca, Michelangelo or Melozzo da Forlì; as far as death perception is concerned. Death as an oblivion into which past glories fall in cities like Ferrara or Venice, and eventually as a distinctive feature of the fifteenth century, a complex and contradictory era in all its greatness.

The deep and original Muratov's remarks originate an eloquent and prolific dialogue between Russian culture at the beginning of the twentieth century, and Italian Renaissance culture.

Keywords: Muratov, Renaissance, Italy, death, art

\section{Pavel Muratov i slika smrti u italijanskoj renesansi}

\section{Rezime}

Cilj ovog rada je da se analitički istraže neki izrazi iz domena kulture, filozofije, književnosti i umetnosti, koje je kao humanističku i renesansnu obradu teme smrti preuzeo i interpretirao Pavel Muratov, autor poznatog dela Slike Italije objavljenog u periodu od 1911. do 1913. Ugledni istoričar umetnosti se više puta bavi pojmom i slikom smrti, koja je bila inspiracija umetnika kao što su Đovani Belini (Giovanni Bellini), Pjero dela Frančeska (Piero della Francesca), Mikelanđelo (Michelangelo) ili Meloco iz Forlija (Melozzo da Forli), percepcijom smrti kao zaboravom koji briše tragove velikana iz prošlosti, u gradovima kao što su Ferara ili Venecija, najzad, nastoji da prati motiv smrti na kraju jedne kompleksne i kontradiktorne epohe u svoj njenoj veličini, kao što je XV vek.

Duboka i originalna zapažanja Muratova, u osnovi su veoma plodnog dijaloga između ruske kulture s početka XX veka i italijanske renesansne kulture.

Ključne reči: Muratov, renesansa, Italija, smrt, umetnost 